\title{
Effect of Gaseous Ozone Exposure on the Bacteria Counts and Oxidative Properties of Ground Hanwoo Beef at Refrigeration Temperature
}

\author{
Youngjae Cho ${ }^{1}$, Muhlisin, Ji Hye Choi, Tae-Wook Hahn ${ }^{1}$, and Sung Ki Lee* \\ Department of Animal Products and Food Science, Kangwon National University, Chuncheon 200-701, Korea \\ ${ }^{1}$ College of Veterinary Medicine and Institute of Veterinary Science, Kangwon National University, \\ Chuncheon 200-701, Korea
}

\begin{abstract}
This study was designed to elucidate the effect of ozone exposure on the bacteria counts and oxidative properties of ground Hanwoo beef contaminated with Escherichia coli O157:H7 at refrigeration temperature. Ground beef was inoculated with $7 \mathrm{Log} \mathrm{CFU} / \mathrm{g}$ of $E$. coli $\mathrm{O} 157: \mathrm{H} 7$ isolated from domestic pigs and was then subjected to ozone exposure $(10 \times 10$ ${ }^{-6} \mathrm{~kg} \mathrm{O}_{3} \mathrm{~h}^{-1}$ ) at $4{ }^{\circ} \mathrm{C}$ for $3 \mathrm{~d}$. E. coli $\mathrm{O} 157: \mathrm{H} 7$, total aerobic and anaerobic bacterial growth and oxidative properties including instrumental color changes, TBARS, catalase (CAT) and glutathione peroxidase (GPx) activity were evaluated. Ozone exposure significantly prohibited $(p<0.05)$ the growths of $E$. coli $\mathrm{O} 157: \mathrm{H} 7$, total aerobic and anaerobic bacteria in ground beef samples during storage. Ozone exposure reduced $(p<0.05)$ the CIE $\mathrm{a}^{*}$ value of samples over storage time. The CIE L* and CIE $b^{*}$ values of the samples fluctuated over storage time, and ozone had no clear effect. Ozone exposure increased the TBARS values during 1 to $3 \mathrm{~d}$ of storage $(p<0.05)$. The CAT and GPx enzyme activities were not affected by ozone exposure until 2 and $3 \mathrm{~d}$ of storage, respectively. This study provides information about the use of ozone exposure as an antimicrobial agent for meat under refrigerated storage. The results of this study provide a foundation for the further application of ozone exposure by integrating an ozone generator inside a refrigerator. Further studies regarding the ozone concentrations and exposure times are needed.
\end{abstract}

Keywords: ozone, ground Hanwoo beef, Escherichia coli O157:H7, bacteria counts, oxidative properties

\section{Introduction}

The food industry is developing sanitizing methods to produce safe food products. Many methods have been used by food industry, such as washing with acid and salts (Latha et al., 2009), the use of chlorine dioxide (Lu and $\mathrm{Wu}, 2012$; Sheen et al., 2011) and irradiation with gamma-rays (Jouki, 2013). Recently, attention has focused on ozone because of its powerful sanitizing effect; this gas can be applied in the food industry to eliminate bacteria and to inactivate viruses, fungi and mycotoxins (Cardenas et al., 2011). The use of ozone has increased due to its designation as Generally Recognized as Safe (GRAS) by the Ministry of Food and Drug Safety (MFDS) in 1997 (Kim et al., 1999).

In the early $19^{\text {th }}$ century, ozone was commercially used

\footnotetext{
*Corresponding author: Sung Ki Lee, Department of Animal Products and Food Science, Kangwon National University, Chuncheon 200-701, Korea. Tel: +82-33-250-8646, Fax: +8233-251-7719, E-mail: skilee@kangwon.ac.kr
}

for the deodorization of industrial waste and the disinfection of drinking water (Uradzinski et al., 2005). Ozone has broad-spectrum antimicrobial activity in water and wastewater and is regarded as a potential bactericidal and virucidal agent (Greene et al., 2012). Bacterial inactivation by ozone is a complex process. However, ozone has been well established to disrupt the cell membrane and cell wall constituents of bacteria, leading to cell lysis (Greene et al., 2012). Ozone also may affect membrane-bound enzymes and damage proteins and DNA (Komanapalli and Lau, 1996). The disruption or lysis of cell walls by ozone is a faster bacterial inactivation mechanism than inactivation by disinfectants, which require time to permeate the cell membrane (Pascual et al., 2007).

Many studies have reported the effects of ozone on foodborne pathogens, such as Salmonella, Listeria monocytogenes, Staphylococcus aureus (Restaino et al., 1995), Pseudomonas fluorescens and Leuconostoc mesenteroides (Kim and Yousef, 2000). Ozone is used in a wide variety of agricultural products, such as vegetables, fruits and fish (Greene et al., 2012). However, only a limited 
number of studies have reported the effect of ozonation on meat products. Sekhon et al. (2010) studied the effect of ozone on the volatile composition of dry-cured ham. Stivarius et al. (2002) reported on the effect of beef trimming decontamination with ozone on ground beef, and Cardenas et al. (2011) reported the action and effects of short-duration ozonation on beef quality attributes.

The use of ozone as an antibacterial agent in meat products is a challenge for the meat industry due to its high oxidative properties. Ozone damages fatty acids in the cell membrane and damages cellular proteins through oxidation (Sekhon et al., 2010). Greene et al. (2012) have reported that the ozonation of lipids leads to the formation of peroxides, and Cataldo (2003) have reported that ozone oxidizes aromatic amino acids. Moreover, the instability of ozone, which can be decomposed in water into strong pro-oxidants such as hydroxyl, hydroperoxy and superoxide radicals, may result in the lipid oxidation of food (Greene et al., 2012). Cells respond to oxidative stress caused by ozone by stimulating the expression of antioxidant enzymes such as catalase, glutathione peroxidase (GPx) and superoxide dismutase (SOD) (Frischer et al., 1997; Lee et al., 2003). However, information regarding the effect of ozone on the oxidative properties of meat is limited.

This study was conducted to evaluate the effects of ozone exposure on the oxidative properties and bacterial growth on ground beef inoculated with the Escherichia coli $\mathrm{O} 157: \mathrm{H} 7$. The oxidative properties of the samples were evaluated through the measurements of TBARS, instrumental color changes and catalase and GPx enzyme activities during refrigerated storage.

\section{Materials and Methods}

\section{Sample preparation}

The longissimus dorsi muscle of Hanwoo (Korean native cattle) was obtained from local markets on the day of the experiment in the air packaging state. The muscle was prepared by removing fat and the surface of the meat that was directly exposed to air during air packaging in the markets. The muscle was ground through a $3 \mathrm{~mm}$ plate using a meat grinder (DFG 450, Daehan Food Machine Co., Ltd., Korea). Approximately $20 \mathrm{~g}$ of sample weighed on a sterilized petridish $(\varnothing 60 \mathrm{~mm} \times 15 \mathrm{~mm}$; SPL Life Sciences, Korea) was used for inoculation.

The inoculated and non-inoculated samples were placed in an air chamber (contains normal air composition, $\pm 21 \%$ of oxygen, $\pm 78 \%$ nitrogen and $<1 \%$ of other gases), or ozone chamber. The chambers $(L \times W \times H=25 \times 20 \times 20 \mathrm{~cm})$ were cleaned with $70 \%$ ethanol to eliminate potential contaminants prior to the ozonation assay. The chamber was equipped with an ozone generator (NOAH environmental clean, Korea) that produced a continuous flux of ozone $\left(10 \times 10^{-6} \mathrm{~kg} \mathrm{O}_{3} \mathrm{~h}^{-1}\right)$. The ozone generator generates electric tension to produce ozone and negative ions. During the experiment, the ozone generator was set to on for 15 min and off for 45 min using an automatic timer plug (Theben 0260.0, Germany). Both the air and ozone chambers were placed in a refrigerator at $4^{\circ} \mathrm{C}$ for $3 \mathrm{~d}$. Quality assessment was conducted on every day of storage.

\section{Preparation of bacteria}

The E. coli $\mathrm{O} 157: \mathrm{H} 7$ used in this study was kindly provided by Bayer Korea (Korea) and isolated from domestic pigs. E. coli $\mathrm{O} 157: \mathrm{H} 7$ was grown at $37^{\circ} \mathrm{C}$ in LuriaBertani (LB) broth (Difco, USA) overnight, washed two times with $0.1 \%$ sterile peptone water and measured for optical density (OD). The colony forming units (CFU) of E. coli $\mathrm{O} 157: \mathrm{H} 7$ were then evaluated on Sorbitol MacConkey agar (Becton Dickinson, USA).

\section{Microbiological analysis}

Ground Hanwoo beef samples ( $\mathrm{n}=32$ ) were divided into 4 groups to evaluate the antimicrobial activity of ozone at $4^{\circ} \mathrm{C}$ for $4 \mathrm{~d}$. Two groups were inoculated with $100 \mu \mathrm{L}$ of E. coli $\mathrm{O} 157: \mathrm{H} 7\left(10^{7} \mathrm{CFU} / \mathrm{mL}\right)$, which was applied to the meat surface and spread with sterile spatulas. Subsequently, the inoculated and non-inoculated groups were each placed in either an air or ozone chamber.

To determine the CFU of the meat samples, duplicate samples were taken every $24 \mathrm{~h}$. Each sample $(1 \mathrm{~g})$ was diluted with $9 \mathrm{~mL}$ of $0.1 \%$ sterile peptone water and homogenized for $2 \mathrm{~min}$ in a Stomacher (Lab blender 400 Seward Laboratory, UK). Decimal dilutions were then performed, and diluted samples were plated on Sorbitol MacConkey agar (Becton Dickinson) for total E. coli and Plate Count Agar (PCA; Difco) for total aerobic and anaerobic bacteria. The plates were incubated aerobically at $37^{\circ} \mathrm{C}$ for $24 \mathrm{~h}$ to enumerate the E. coli and total aerobic bacteria. For anaerobic bacteria enumeration, the PCA plates were placed on an anaerobe container (BD GasPak EZ, USA). The container was incubated at $37^{\circ} \mathrm{C}$ for $24 \mathrm{~h}$.

\section{Instrumental color}

Changes in the color of the surface of the ground Hanwoo beef during ozonation were monitored by measuring CIE L* (lightness), CIE a* (redness) and CIE b* (yellow- 
ness) using a color difference meter (CR-400, Konica Minolta Sensing Inc., Osaka, Japan) and an illuminant C. The color instrument was calibrated using white plates ( $\mathrm{Y}=93.6, \mathrm{x}=0.3134$ and $\mathrm{y}=0.3194$ ) before measurement. The instrumental color measurements were directly performed on the surface of the samples immediately after the samples were taken out of the chamber.

\section{Thiobarbituric acid reactive substances (TBARS)}

TBARS is a strong objective predictor of lipid oxidation prior to the rancidity of meat (McMillin, 2008). The TBARS analysis was performed according to the method by Sinnhuber and Yu (1977). Each $0.5 \mathrm{~g}$ of sample was mixed with 3 drops of antioxidant solution (3\% BHA$54 \%$ propylene glycol-3\% BHT-40\% Tween 20 ), $3 \mathrm{~mL}$ of TBA solution and $17 \mathrm{~mL}$ of $25 \%(\mathrm{w} / \mathrm{v})$ trichloroacetic acid (TCA). The sample mixture was incubated in a water bath at $100^{\circ} \mathrm{C}$ for $30 \mathrm{~min}$. After cooling, $5 \mathrm{~mL}$ of the mixture was removed and centrifuged at $3,500 \mathrm{rpm}$ for 30 min. The absorbance of the supernatant was measured at $532 \mathrm{~nm}$ using a spectrophotometer (UVmini-1240, Shimadzu, Japan). The results were calculated as $\mathrm{mg}$ of malonaldehyde (MA) per $\mathrm{kg}$ of sample.

\section{Determination of antioxidant enzyme activity}

Catalase. The activity of catalase was measured according to a method described by Aebi (1984) with modification. A $5 \mathrm{~g}$ sample was homogenized with $25 \mathrm{~mL}$ of $50 \mathrm{mM}$ sodium phosphate buffer ( $\mathrm{pH}$ 7.0) using a homogenizer (Ultra-Turrax T25 basic, IkaWerke GmbH \& Co., Germany) at $13,500 \mathrm{rpm}$ for $15 \mathrm{sec}$ in an ice bath. The homogenate was centrifuged at $3,000 \mathrm{rpm}$ at $2^{\circ} \mathrm{C}$ for 15 min, and the supernatant was removed and filtered with Whatman filter paper No. 1 . Then, $100 \mu \mathrm{L}$ of supernatant was mixed well with $2.9 \mathrm{~mL}$ of $30 \mathrm{mM} \mathrm{H}_{2} \mathrm{O}_{2}$, and decrease in absorbance was recorded at $240 \mathrm{~nm}$ every $30 \mathrm{sec}$ for $3 \mathrm{~min}$. The catalase activity was calculated as follows:

Catalase activity (Units per $\mathrm{g} /$ meat $)=$

$$
\frac{3.45 \times \text { dilution factor of }(6)}{t \min \times 0.1}
$$

The number 3.45 corresponds to the decomposition of 3.45 micromoles of hydrogen peroxide in a $3.0 \mathrm{~mL}$ reaction mixture to produce a decrease in the A240 nm from 0.45 to 0.40 absorbance units. T-min corresponds to the time in minutes required for the A240 to decrease from 0.45 to 0.40 absorbance units, and 0.1 represents the volume of meat extract (in $\mathrm{mL}$ ). The catalase activity was expressed as units/g sample.
Glutathione peroxidase (GPx). For the measurement of GPx activity, $5 \mathrm{~g}$ of sample was homogenized in $25 \mathrm{~mL}$ of $50 \mathrm{mM}$ of phosphate buffer and $1 \mathrm{mM}$ EDTA using a homogenizer at 13,500 rpm for $30 \mathrm{sec}$. The homogenate was centrifuged at $3000 \mathrm{rpm}$ for $10 \mathrm{~min}$ at $4{ }^{\circ} \mathrm{C}$ followed by filtration of the supernatant using Whatman filter paper No 1 . Then, $100 \mu \mathrm{L}$ of the supernatant was incubated with $4900 \mu \mathrm{L}$ of assay mixture containing 5 units/mL glutathione reductase (Sigma G3664) in phosphate buffer, $10 \mathrm{mM}$ glutathione (Sigma G4251), 1.5 mM NADPH (Sigma N 1630), $1.5 \mathrm{mM} \mathrm{H}_{2} \mathrm{O}_{2}$ (Sigma H1009) and $100 \mathrm{mM} \mathrm{NaN}_{3}$. The GPx activity was measured by recording the decrease in the absorbance of the incubation mixture at $340 \mathrm{~nm}$ over $3 \mathrm{~min}$. The GPx was expressed as units/g sample.

\section{Statistical analysis}

All values are reported as the mean \pm standard deviation for each treatment group. Analysis of variance (ANOVA) was performed using the General Linear Model (GLM) procedure of SPSS, version 19.0 (SPSS, 2010), followed by Duncan's multiple range tests. The level of significance was established at $p<0.05$.

\section{Results and Discussion}

\section{Microbiological analysis}

Samples of ground Hanwoo beef were inoculated with E. coli $\mathrm{O} 157: \mathrm{H} 7$ to evaluate the effect of ozone exposure at refrigeration temperature for $3 \mathrm{~d}$, because this bacteria recently has caused major outbreaks worldwide (Table 1). The CFU values of all the samples at each time point were reduced by ozone exposure compared with nonozone exposure.

The initial concentrations of $E$. coli $\mathrm{O} 157: \mathrm{H} 7$ in the inoculated beef samples were $4.47 \mathrm{Log} \mathrm{CFU} / \mathrm{g}$. No growth of $E$. coli $\mathrm{O} 157: \mathrm{H} 7$ was observed in the non-inoculated beef samples. The E. coli O157:H7 counts in the inoculated samples that were exposed to ozone were reduced by $0.53 \mathrm{Log} \mathrm{CFU} / \mathrm{g}$ on $1 \mathrm{~d}$, compared with those without ozone exposure. This result agrees with a previous study showing that $12 \times 10^{-6} \mathrm{~kg} \mathrm{O}_{3} \mathrm{~h}^{-1}$ of ozone treatment reduced the CFU by $0.65 \mathrm{Log} \mathrm{CFU} / \mathrm{g}$ in a circular beef sample cut from a carcass at $5^{\circ} \mathrm{C}$ on $1 \mathrm{~d}$ after the samples were inoculated with $50 \mu \mathrm{L}$ of $10^{8} \mathrm{CFU} / \mathrm{mL}$ of E. coli O157:H7 (Cardenas et al., 2011). Although CFU reduction by the effect of ozone exposure was clear on $1 \mathrm{~d}$, $\mathrm{CFU}$ were gradually increased from $2 \mathrm{~d}$. This effect seems to be caused by the limit of ozone exposure. Ozone exposure could eliminate only the E. coli $\mathrm{O} 157: \mathrm{H} 7$ conta- 
Table 1. Effect of ozone exposure on the $E$. coli O157:H7, total aerobic and anaerobic bacteria counts (log CFU/g) of ground Hanwoo beef inoculated with $E$. coli $0157:$ H7

\begin{tabular}{|c|c|c|c|c|c|c|}
\hline \multirow{2}{*}{ Bacteria } & \multirow{2}{*}{$\begin{array}{l}\text { Inoculation with } \\
\text { E. coli } \mathrm{O} 157: \mathrm{H} 7\end{array}$} & \multirow{2}{*}{$\begin{array}{c}\text { Ozone } \\
\text { treatment }\end{array}$} & \multicolumn{4}{|c|}{ Storage (d) } \\
\hline & & & 0 & 1 & 2 & 3 \\
\hline \multirow{2}{*}{ E. coli $\mathrm{O} 157: \mathrm{H} 7$} & \multirow{2}{*}{ Yes } & No & $4.47 \pm 0.06^{\mathrm{B}}$ & $5.47 \pm 0.15^{\mathrm{aA}}$ & $5.97 \pm 0.85^{\mathrm{aA}}$ & $5.55 \pm 0.41^{\mathrm{aA}}$ \\
\hline & & Yes & $4.47 \pm 0.06^{\mathrm{A}}$ & $3.94 \pm 0.33^{\mathrm{bB}}$ & $4.29 \pm 0.29^{\mathrm{bA}}$ & $4.64 \pm 0.69^{\mathrm{bA}}$ \\
\hline \multirow{4}{*}{ Total aerobic bacteria } & \multirow{2}{*}{ No } & No & $4.31 \pm 0.10^{\mathrm{D}}$ & $4.86 \pm 0.08^{\mathrm{cC}}$ & $5.34 \pm 0.08^{\mathrm{cB}}$ & $6.70 \pm 0.03^{\mathrm{bA}}$ \\
\hline & & Yes & $4.31 \pm 0.10^{\mathrm{B}}$ & $4.32 \pm 0.04^{\mathrm{dB}}$ & $4.77 \pm 0.21^{\mathrm{dB}}$ & $5.67 \pm 0.11^{\mathrm{cA}}$ \\
\hline & \multirow{2}{*}{ Yes } & No & $6.55 \pm 0.22^{\mathrm{C}}$ & $7.41 \pm 0.38^{\mathrm{aA}}$ & $7.43 \pm 0.15^{\mathrm{aA}}$ & $7.15 \pm 0.22^{\mathrm{aB}}$ \\
\hline & & Yes & $6.55 \pm 0.22$ & $6.54 \pm 0.13^{b}$ & $6.32 \pm 0.28^{\mathrm{b}}$ & $6.69 \pm 0.13^{b}$ \\
\hline \multirow{4}{*}{ Total anaerobic bacteria } & \multirow{2}{*}{ No } & No & $4.44 \pm 0.14^{\mathrm{C}}$ & $3.80 \pm 0.71^{\mathrm{bC}}$ & $5.11 \pm 0.20^{\mathrm{cB}}$ & $6.25 \pm 0.23^{\mathrm{cA}}$ \\
\hline & & Yes & $4.44 \pm 0.14^{\mathrm{B}}$ & $3.46 \pm 0.31^{\mathrm{bC}}$ & $4.49 \pm 0.41^{\mathrm{cB}}$ & $5.56 \pm 0.29^{\mathrm{dA}}$ \\
\hline & \multirow{2}{*}{ Yes } & No & $6.69 \pm 0.19^{\mathrm{B}}$ & $7.10 \pm 0.20^{\mathrm{aAB}}$ & $7.44 \pm 0.03^{\mathrm{aA}}$ & $7.10 \pm 0.16^{\mathrm{aAB}}$ \\
\hline & & Yes & $6.69 \pm 0.19$ & $6.73 \pm 0.51^{\mathrm{a}}$ & $6.65 \pm 0.20^{\mathrm{b}}$ & $6.65 \pm 0.24^{b}$ \\
\hline
\end{tabular}

Mean values \pm standard deviation.

${ }^{\mathrm{a}-\mathrm{d}}$ Means in the same column followed by different superscript letters in lower-case are significantly different $(p<0.05)$.

${ }^{A-D}$ Means in the same row followed by different superscript letters in upper-case are significantly different $(p<0.05)$.

mination on the surface of the beef sample, not that inside the sample.

The CFU changes in the total aerobic and anaerobic bacteria were also evaluated on $3 \mathrm{~d}$. They showed similar reduction patterns in the samples with ozone exposure. However, a significant reduction was shown in the total aerobic bacterial count of the ozone-exposed samples on $3 \mathrm{~d}$ compared with the non-ozone exposed samples. Compared with the non-inoculated samples, the total aerobic and anaerobic bacterial counts in the E. coli $\mathrm{O} 157: \mathrm{H} 7$ inoculated samples increased less over time. Even though ozone exposure could not significantly decrease CFU in the ground beef samples, it could clearly prohibit the bacterial growth during $3 \mathrm{~d}$ of storage. This finding indicates that ozone exposure continuously eliminated $E$. coli $\mathrm{O} 157: \mathrm{H} 7$ on the surface of the beef samples and it can be an antibacterial agent for meat products in refrigerator because the most of initial contamination of pathogen occurs in the surface of meat products.

\section{Instrumental color}

Color is the most important factor influencing the preference of consumers with respect to meat, and a red color is usually associated with the freshness of meat (Mancini and Hunt, 2005). The effects of gaseous ozone treatment and inoculation on the surface color of ground Hanwoo beef are presented in Table 2 . There was no significant difference $(p>0.05)$ in CIE $\mathrm{a}^{*}$ between the inoculated and non-inoculated samples during storage except on $0 \mathrm{~d}$, when the CIE a* of the E. coli $\mathrm{O} 157: \mathrm{H} 7$-inoculated samples was significantly lower $(p<0.05)$ than that of the non-inoculated samples. The initial CIE a* of the E. coliinoculated samples was lower than that of the non-inocu- lated samples. The lower value of CIE $\mathrm{a}^{*}$ might be related to the $100 \mu \mathrm{L}$ of peptone water per gram of sample that was added during the inoculation. The water might cover the surface of the meat, reducing the contact between the myoglobin in the meat and the oxygen in the air. Oxygen is required for myoglobin to remain in its oxygenated form (oxymyoglobin), which produces the bright cherry color in meat (Mancini and Hunt, 2005). The instrumental color measurement was performed $30 \mathrm{~min}$ after the inoculation. During this time, the myoglobin of the non-inoculated samples reacted with oxygen to form oxymyoglobin, whereas that of the inoculated samples did not due to the presence of water on the surface.

Ozone exposure significantly decreased CIE a* $(p<0.05)$ from 24 to $72 \mathrm{~h}$ of storage regardless of the E. coli $\mathrm{O} 157$ : $\mathrm{H} 7$ inoculation status. Our results are in accordance with those of Cardenas et al. (2011), who found lower CIE a* values of beef exposed continuously to ozone for $24 \mathrm{~h}$. An ozone-induced decrease of CIE $\mathrm{a}^{*}$ during the storage of beef steak and ground beef was also reported by Unda et al. (1989) and Stivarius et al. (2002), respectively. The decrease in $\mathrm{CIE} \mathrm{a}^{*}$ was due to the oxidation of myoglobin and oxymyoglobin to metmyoglobin by the ozone exposure. Ozone and other reactive oxygen species (ROS) are strong oxidants that initiate lipid and myoglobin oxidation (Bekhit et al., 2013). The oxidation of myoglobin produces metmyoglobin, which caused the discoloration of meat that is characterized by lower redness (Mancini and Hunt, 2005). The decreases in CIE a* in the samples exposed to ozone (Table 1) was coupled to increases in the TBARS values (Table 2). Similar findings of increased lipid oxidation and decreased CIE $\mathrm{a}^{*}$ due to the formation of metmyoglobinin meat under oxidized condi- 
Table 2. Effect of ozone exposure on the instrumental color of ground Hanwoo beef inoculated with E. coli O157:H7 at refrigeration temperature

\begin{tabular}{|c|c|c|c|c|c|c|}
\hline \multirow{2}{*}{ Bacteria } & \multirow{2}{*}{$\begin{array}{l}\text { Inoculation with } \\
\text { E. coli } \mathrm{O} 157: \mathrm{H} 7\end{array}$} & \multirow{2}{*}{$\begin{array}{c}\text { Ozone } \\
\text { treatment }\end{array}$} & \multicolumn{4}{|c|}{ Storage $(\mathrm{d})$} \\
\hline & & & 0 & 1 & 2 & 3 \\
\hline \multirow{4}{*}{ Lightness (CIE L*) } & \multirow{2}{*}{ No } & No & $44.2 \pm 1.6^{\mathrm{B}}$ & $46.1 \pm 1.7^{\mathrm{bB}}$ & $45.8 \pm 2.7^{\mathrm{aB}}$ & $51.8 \pm 4.8^{\mathrm{aA}}$ \\
\hline & & Yes & $44.2 \pm 1.7^{\mathrm{C}}$ & $48.8 \pm 2.5^{\mathrm{aA}}$ & $46.0 \pm 2.3^{\mathrm{aBC}}$ & $48.7 \pm 2.83^{\mathrm{abA}}$ \\
\hline & \multirow{2}{*}{ Yes } & No & $44.5 \pm 1.3^{\mathrm{B}}$ & $45.3 \pm 2.1^{\mathrm{bB}}$ & $44.7 \pm 2.0^{\mathrm{abB}}$ & $47.6 \pm 2.8^{\mathrm{bA}}$ \\
\hline & & Yes & $44.5 \pm 1.3^{\mathrm{B}}$ & $45.5 \pm 3.3^{\mathrm{bB}}$ & $43.7 \pm 1.5^{\mathrm{bB}}$ & $47.6 \pm 2.1^{\mathrm{bA}}$ \\
\hline \multirow{4}{*}{ Redness (CIE a*) } & \multirow{2}{*}{ No } & No & $16.4 \pm 1.3^{\mathrm{aA}}$ & $14.4 \pm 1.3^{\mathrm{bB}}$ & $16.79 \pm 1.5^{\mathrm{aA}}$ & $7.8 \pm 2.3^{\mathrm{bC}}$ \\
\hline & & Yes & $16.4 \pm 1.3^{\mathrm{aA}}$ & $11.3 \pm 1.3^{\mathrm{cB}}$ & $11.3 \pm 1.6^{\mathrm{bB}}$ & $6.7 \pm 0.7^{\mathrm{bC}}$ \\
\hline & \multirow{2}{*}{ Yes } & No & $13.9 \pm 1.3^{\mathrm{bB}}$ & $15.9 \pm 1.2^{\mathrm{aA}}$ & $16.8 \pm 1.0^{\mathrm{aA}}$ & $9.6 \pm 1.4^{\mathrm{aC}}$ \\
\hline & & Yes & $13.9 \pm 1.3^{\mathrm{bA}}$ & $11.2 \pm 1.6^{\mathrm{cC}}$ & $12.3 \pm 0.5^{\mathrm{bB}}$ & $6.7 \pm 0.8^{\mathrm{bD}}$ \\
\hline \multirow{4}{*}{ Yellowness (CIE b*) } & \multirow{2}{*}{ No } & No & $8.7 \pm 0.54^{\mathrm{bAB}}$ & $7.5 \pm 0.8^{\mathrm{bB}}$ & $9.5 \pm 0.8^{\mathrm{aA}}$ & $4.9 \pm 1.6^{\mathrm{bC}}$ \\
\hline & & Yes & $8.7 \pm 0.54^{\mathrm{bAB}}$ & $6.8 \pm 0.9^{\mathrm{bC}}$ & $7.9 \pm 1.4^{\mathrm{bB}}$ & $5.7 \pm 1.3^{\mathrm{abC}}$ \\
\hline & \multirow{2}{*}{ Yes } & No & $9.5 \pm 1.22^{\mathrm{aA}}$ & $8.6 \pm 0.8^{\mathrm{aAB}}$ & $9.5 \pm 0.8^{\mathrm{aA}}$ & $6.0 \pm 1.3^{\mathrm{abB}}$ \\
\hline & & Yes & $9.5 \pm 1.22^{\mathrm{aA}}$ & $7.7 \pm 1.3^{\mathrm{bB}}$ & $9.0 \pm 0.7^{\mathrm{aA}}$ & $6.2 \pm 1.0^{\mathrm{aC}}$ \\
\hline
\end{tabular}

Mean values \pm standard deviation.

${ }^{\mathrm{a}-\mathrm{c}}$ Means in the same column followed by different letters in superscript lower-case are significantly different $(p<0.05)$.

${ }^{\mathrm{A}-\mathrm{C}}$ Means in the same row followed by different letters in superscript upper-case are significantly different $(p<0.05)$.

Table 3. Effect of ozone exposure on TBARS, catalase activity and glutathione peroxidase activity of ground Hanwoo beef inoculated with $E$. coli $0157: \mathrm{H7}$ at refrigeration temperature

\begin{tabular}{|c|c|c|c|c|c|c|}
\hline \multirow{2}{*}{ Bacteria } & \multirow{2}{*}{$\begin{array}{l}\text { Inoculation with } \\
\text { E. coli } \mathrm{O} 157: \mathrm{H} 7\end{array}$} & \multirow{2}{*}{$\begin{array}{l}\text { Ozone } \\
\text { treatment }\end{array}$} & \multicolumn{4}{|c|}{ Storage (d) } \\
\hline & & & 0 & 1 & 2 & 3 \\
\hline \multirow{4}{*}{$\begin{array}{c}\text { TBARS } \\
\text { (mg MA/kg sample) }\end{array}$} & \multirow{2}{*}{ No } & No & $0.66 \pm 0.02^{\mathrm{B}}$ & $0.71 \pm 0.01^{\mathrm{cAB}}$ & $0.72 \pm 0.02^{\mathrm{cA}}$ & $0.74 \pm 0.01^{\mathrm{bA}}$ \\
\hline & & Yes & $0.66 \pm 0.02^{\mathrm{B}}$ & $0.76 \pm 0.03^{\mathrm{bA}}$ & $0.75 \pm 0.01^{\mathrm{bA}}$ & $0.79 \pm 0.06^{\mathrm{abA}}$ \\
\hline & \multirow{2}{*}{ Yes } & No & $0.67 \pm 0.05^{\mathrm{B}}$ & $0.72 \pm 0.02^{\mathrm{cA}}$ & $0.73 \pm 0.02^{\mathrm{cA}}$ & $0.74 \pm 0.02^{\mathrm{bA}}$ \\
\hline & & Yes & $0.67 \pm 0.05^{\mathrm{B}}$ & $0.81 \pm 0.02^{\mathrm{aA}}$ & $0.80 \pm 0.02^{\mathrm{aA}}$ & $0.84 \pm 0.05^{\mathrm{aA}}$ \\
\hline \multirow{4}{*}{$\begin{array}{c}\text { Catalase/CAT activity } \\
\text { (U/g sample) }\end{array}$} & \multirow{2}{*}{ No } & No & $449.2 \pm 27.7^{\mathrm{A}}$ & $438.8 \pm 24.6^{\mathrm{A}}$ & $411.2 \pm 42.9^{\mathrm{abB}}$ & $403.6 \pm 28.07^{\mathrm{abB}}$ \\
\hline & & Yes & $449.2 \pm 27.7^{\mathrm{A}}$ & $426.4 \pm 24.4^{\mathrm{B}}$ & $397.4 \pm 31.2^{\mathrm{bC}}$ & $373.6 \pm 41.78^{\mathrm{bC}}$ \\
\hline & \multirow{2}{*}{ Yes } & No & $449.2 \pm 27.7^{\mathrm{A}}$ & $447.1 \pm 49.1^{\mathrm{A}}$ & $422.2 \pm 23.9^{\mathrm{aB}}$ & $416.7 \pm 43.40^{\mathrm{aB}}$ \\
\hline & & Yes & $449.2 \pm 27.7^{\mathrm{A}}$ & $431.9 \pm 40.3^{\mathrm{A}}$ & $399.5 \pm 27.7^{\mathrm{bB}}$ & $377.7 \pm 56.35^{\mathrm{bC}}$ \\
\hline \multirow{4}{*}{$\begin{array}{l}\text { Glutathione peroxidase } \\
\text { (GPx) activity } \\
\text { (U/g sample) }\end{array}$} & \multirow[b]{2}{*}{ No } & No & $1.26 \pm 0.10^{\mathrm{A}}$ & $1.24 \pm 0.11^{\mathrm{A}}$ & $1.23 \pm 0.15^{\mathrm{A}}$ & $0.86 \pm 0.22^{\mathrm{abB}}$ \\
\hline & & Yes & $1.26 \pm 0.10^{\mathrm{A}}$ & $1.25 \pm 0.11^{\mathrm{A}}$ & $1.17 \pm 0.28^{\mathrm{A}}$ & $0.71 \pm 0.33^{\mathrm{bB}}$ \\
\hline & \multirow{2}{*}{ Yes } & No & $1.26 \pm 0.10^{\mathrm{A}}$ & $1.26 \pm 0.11^{\mathrm{A}}$ & $1.27 \pm 0.14^{\mathrm{A}}$ & $0.92 \pm 0.17^{\mathrm{aB}}$ \\
\hline & & Yes & $1.26 \pm 0.10^{\mathrm{A}}$ & $1.21 \pm 0.13^{\mathrm{A}}$ & $1.18 \pm 0.15^{\mathrm{A}}$ & $0.80 \pm 0.23^{\mathrm{abB}}$ \\
\hline
\end{tabular}

Mean values \pm standard deviation.

${ }^{\mathrm{a}-\mathrm{c}}$ Means in the same column followed by different letters in superscript lower-case are significantly different $(p<0.05)$.

${ }^{\mathrm{A}-\mathrm{C}}$ Means in the same row followed by different letters in superscript upper-case are significantly different $(p<0.05)$.

tions have been reported (Jayasingh et al., 2002; Kim et al., 2010). Lipid oxidation is a promoter of myoglobin oxidation (Lin and Hultin, 1977). Faustman et al. (1989) noted that lipid oxidation, which results in the production of free radicals, is closely coupled to pigment oxidation. The inoculation with $E$. coli reduced the CIE L* of the samples from $1 \mathrm{~d}$ of storage $(p<0.05)$. Ozone exposure did not affect the CIE $\mathrm{L}^{*}$ of the samples throughout storage time. A lower CIE $b^{*}$ was found on the surface of the samples exposed to ozone regardless of the E. coli inoculation status.

\section{Lipid oxidation}

The effect of E. coli O157:H7 inoculation and ozone exposure on lipid oxidation (TBARS) is presented in Table 3. TBARS, expressed as mg of malondialdehyde (MA)/kg of meat, is a strong objective predictor of the perception of rancidity (McMillin, 2008). Our study reported that the TBARS values ranged from $0.67 \mathrm{mg} \mathrm{MA} / \mathrm{kg}$ on $\mathrm{d} 0$ to 0.84 $\mathrm{mg} \mathrm{MA} / \mathrm{kg}$ on $3 \mathrm{~d}$ of storage. According to Tarladgis et al. (1960), values of $0.6 \mathrm{mg} \mathrm{MA} / \mathrm{kg}$ are considered to indicate fresh meat. Our initial sample appeared to be not fresh enough, as reflected by the TBARS value on $0 \mathrm{~d}$ being over the limit. However, the TBARS values of the samples during $3 \mathrm{~d}$ of ozone exposure were regarded as acceptable. A TBARS value of $2 \mathrm{mg} \mathrm{MA} / \mathrm{kg}$ was considered to be the limiting threshold for oxidized meat acceptability (Campo et al., 2006). 
Ozone exposure promoted lipid oxidation regardless of the inoculation status. The TBARS values of both noninoculated and E. coli $\mathrm{O} 157$ :H7-inoculated samples exposed to ozone were significantly higher $(p<0.05)$ than those of samples without ozone exposure. Ozone promotes lipid oxidation in meat. The action of ozone on oxidants causes irreversible damage to the fatty acids in the cell membrane and cellular protein through oxidation (Beuchat, 1992; Luck and Jager, 1998; Sekhon et al., 2010). Ozone $\left(\mathrm{O}_{3}\right)$ is categorized as a non-radical derivative ROS that is mainly responsible for the initiation of the oxidation reaction of foods, particularly in lipids, where it destroys essential fatty acids (Choe and Min, 2005). Moreover, ozone gas is unstable and decays naturally into diatomic oxygen (Finch and Fairbairn, 1991). During continuous exposure, the oxygen generated by ozone degradation might increase. Many studies have reported on the effect of oxygen on the promotion of the lipid oxidation in meat (Kim et al., 2010; Li et al., 2012; Vitale et al., 2014). Among samples exposed to ozone, a higher TBARS $(p<0.05)$ was found in E. coli $\mathrm{O} 157: \mathrm{H} 7$-inoculated samples than in non-inoculated samples. The higher population of bacteria counted on E. coli $\mathrm{O} 157: \mathrm{H} 7$-inoculated samples than on non-inoculated samples (Table 1) seemed to escalate the lipid oxidation. The influence of microbial populations on the accumulation of lipid oxidation products was also reported by Rhee et al. (2006) for beef.

\section{Activity of catalase (CAT) and glutathione peroxi- dase (GPx)}

The effects of the ozone treatment on the CAT and GPx activities are presented in Table 3. The CAT activity of the non-inoculated samples exposed to ozone decreased significantly $(p<0.05)$ from $1 \mathrm{~d}$ of storage but decreased starting from $2 \mathrm{~d}$ of storage in other samples. The decrease in CAT activity was greater in those samples under ozone exposure than in those with no ozone exposure, which had relatively stable CAT activity. The relatively stable CAT activity of beef muscles under aerobic conditions was also reported by Renerre et al. (1996). Pradhan et al. (2000) found stable CAT activity in ground beef during $6 \mathrm{~d}$ of aerobically refrigerated storage. There were no effects of $E$. coli $\mathrm{O} 157: \mathrm{H7}$ - inoculation and ozone on CAT activity on $0 \mathrm{~d}$ and $1 \mathrm{~d}$ of storage ( $p>0.05)$. E. coli $\mathrm{O}$ 157:H7 inoculation did not affect the CAT activity ( $p>$ $0.05)$. Ozone exposure significantly reduced the CAT activity $(p<0.05)$ starting from $2 \mathrm{~d}$ of storage regardless of the E. coli $\mathrm{O} 157: \mathrm{H} 7$ inoculation status. Whiteside and
Hassan (1988) reported catalase inactivation caused by the exposure to ozone gas. They also noted that the inactivation of catalase by ozone depended on the time exposure and $\mathrm{pH}$ level. Lee et al. (2003) suggested that the inactivation of catalase by ozone was primarily due to damages in protein moieties, which subsequently led to heme release.

The GPx activity of all samples was stable from 0 to $2 \mathrm{~d}$ of storage regardless of $E$. coli $\mathrm{O} 157: \mathrm{H} 7$ inoculation status and ozone exposure. On $3 \mathrm{~d}$ of storage, a significant decrease $(p<0.05)$ in GPx activity occurred in all treatments. There was no significant $(p>0.05)$ effect of $E$. coli $\mathrm{O} 157: \mathrm{H} 7$ inoculation and ozone on the activity of the GPx enzyme from 0 to $2 \mathrm{~d}$ of storage. On the last day of storage, ozone exposure significantly decreased the GPx activity regardless of the E. coli $\mathrm{O} 157: \mathrm{H} 7$ inoculation status. These results indicate that GPx was more resistant to ozone than CAT. This result is in accordance with that of Lee et al. (2003). CAT and GPx, together with superoxide dismutase (SOD), are known to act to prevent the accumulation of lipid oxidation products (Decker and $\mathrm{Xu}$, 1998; Terevinto et al., 2010). As the activity of CAT and GPx was reduced by ozone, these enzymes lost their abilities, which resulted in increased lipid oxidation rates. This outcome can be an additional explanation for the higher TBARS values found in samples under ozone exposure (Table 3 ).

\section{Conclusion}

Ozone exposure $\left(10 \times 10^{-6} \mathrm{~kg} \mathrm{O}_{3} \mathrm{~h}^{-1}\right)$ significantly reduced the growth of E. coli $\mathrm{O} 157: \mathrm{H} 7$ in E. coli $\mathrm{O} 157: \mathrm{H} 7-$ inoculated ground beef samples during $3 \mathrm{~d}$ of storage. Similar results were also found for total aerobic and total anaerobic bacteria, in which the ozone exposure reduced the bacterial counts. Ozone exposure promoted lipid oxidation regardless of the inoculation status. The TBARS values of both non-inoculated and E. coli O157:H7-inoculated samples exposed to ozone were significantly higher than those of samples without ozone exposure. However, the TBARS values of samples were regarded as acceptable until the end of storage. Ozone also promoted the oxidation of myoglobin and oxymyoglobin to metmyoglobin. As a result, lower levels of redness were observed in samples under ozone exposure. The CAT and GPx activities decreased with increasing storage time. Ozone exposure slightly reduced the CAT activity from 2 to $3 \mathrm{~d}$ of storage and the GPx activity on $3 \mathrm{~d}$ of storage. 


\section{Acknowledgments}

This study was supported by 2013 research grant from Kangwon National University (No. 120131247) and Bioindustry Technology Development Program, Ministry for Food, Agriculture, Forestry and Fisheries, Republic of Korea (No. 112130-3).

\section{References}

1. Aebi, H. E. (1984) Catalase in vitro. Method Enzymol. 105, 121-126.

2. Bekhit, A. E. D. A., Hopkins, D. L., Fahri, F. T., and Ponnampalam, E. N. (2013) Oxidative processes in muscle systems and fresh meat: sources, markers, and remedies. Compr. Rev. Food Sci. F. 12, 565-597.

3. Beuchat, L. R. (1992) Surface disinfection of raw produce. Diary Food Environ. Sanitat. 12, 6-9.

4. Botzenhart, K., Tarcsoon, G. M., and Ostruschka, M. (1993) Inactivation of bacteria and coliphages by ozone and $\mathrm{ClO}_{2}$ in a continuous flow reactor. Water Sci. Technol. 27, 363-370.

5. Brewer, M. S. (2009) Irradiation effects on meat flavor: A review. Meat Sci. 81, 1-14.

6. Campo, M. M., Nute, G. R., Hughes, S. I., Enser, M., Wood, J. D., and Richardson, R. I. (2006) Flavor perception of oxidation in beef. Meat Sci. 72, 303-311.

7. Cardenas, F. C., Andres, S., Giannuzi, L., and Zaritzky, N. (2011) Antimicrobial action and effects on beef quality attributes of a gaseous ozone treatment at refrigeration temperatures. Food Control 22, 1442-1447.

8. Cataldo, F. (2003) On the action of ozone on proteins. Polym. Degrad. Stabil. 82, 105-114.

9. Choe, E. and Min, D. B. (2005) Chemistry and reactions of reactive oxygen species in food. J. Food Sci. 70, 142-159.

10. Decker, E. A. and Xu, Z. (1998) Minimizing rancidity in muscle foods. Food Technol. 52, 54-59.

11. Faustman, C., Cassens, R. G., Schaefer, D. M., Buege, D. R., and Schelle, K. K. (1989) Vitamin E supplementation of Holstein steer diets improves sirloin steak color. J. Food Sci. 54, 485-486.

12. Finch, G. R. and Fairbairn, N. (1991) Comparative inactivation of poliovirus type 3 and MS2 coliphage in demand free phosphate buffer by using ozone. Appl. Environ. Microb. 57, 3121-3126.

13. Frischer, T., Pullwitt, A., Kuhr, J., Meinert, R., Haschke, N., Studnicka, M., and Lubec, G. (1997) Aromatic hydroxylation in nasal lavage fluid following ambient ozone exposure. Free Radical Bio. Med. 22, 201-207.

14. Greene, A. K., Guzel-Seydim, Z. B., and Seydim, A. C. (2012) Chemical and physical properties of ozone. In:Ozone in food processing. O'Donnell, C., Tiwari, B. K., Cullen, P. J., and Rice, R. G., (ed) Blackwell Publishing, Ltd., Oxford, pp. 1932.

15. Jayasingh, P., Cornforth, D. P., Brennand, C. P., Carpenter, C. E., and Whittier, D. R. (2002) Sensory evaluation of ground beef stored in high-oxygen modified atmosphere packaging. J. Food Sci. 67, 3493-3496.

16. Jouki, M. (2013) Evaluation of gamma irradiation and frozen storage on microbial load and physico-chemical quality of turkey breast meat. Radiat. Phys. Chem. 85, 243-245.

17. Kim, J. G. and Yousef, A. E. (2000) Inactivation kinetics of foodborne spoilage and pathogenic bacteria by ozone. J. Food Sci. 65, 521-528.

18. Kim, J. G., Yousef, A., and Chism, G. (1999) Use of ozone to inactivate microorganisms on lettuce. J. Food Safety 19, 1733.

19. Kim, Y. H., Huff-Lonergan, E., Sebranek, J. G., and Lonergan, S. M. (2010) High-oxygen modified atmosphere packaging system induces lipid and myoglobin oxidation and protein polymerization. Meat Sci. 85, 759-767.

20. Komanapalli, I. R. and Lau, B. H. S. (1996) Ozone-induced damage of Escherichia coli K-12. Appl. Microbiol. Bio. 46, 610-614.

21. Latha, C., Sherikar, A. T., Waskar, V. S., Dubal, Z. B., and Ahmed, S. N. (2009) Sanitizing effect of salts on experimentally inoculated organisms on pork carcasses. Meat Sci. 83, 796-799.

22. Lee, Y. K., Kim, S. M., and Han, S. (2003) Ozone-induced inactivation of antioxidant enzymes. Biochimie 85, 947-952.

23. Lin, T. S. and Hultin, H. O. (1977) Oxidation of myoglobin in vitro mediated by lipid oxidation in microsomial fractions of muscle. J. Food Sci. 42, 136-140.

24. Li, X., Lindahl, G., Zamaratskaia, G., and Lundstrom, K. (2012) Inuence of vacuum skin packaging on color stability of beef longissimus lumborum compared with vacuum and high-oxygen modied atmosphere packaging. Meat Sci. 92, 604-609.

25. Lu, Y. and Wu, C. (2012) Reduction of Salmonella enterica on chicken breast by thymol, acetic acid, sodium dodecyl sulfate or hydrogen peroxide combinations as compared to chlorine was. Int. J. Food Microbiol.152, 31-34.

26. Luck, E. and Jager, M. (1998) Antimicrobial food additives. 2nd ed, Springer-Verlag. NY, pp. 42-43.

27. Mancini, R. A. and Hunt, M. C. (2005) Current research in meat color: review. Meat Sci. 80, 43-65.

28. McMillin, K. W. (2008) Where is MAP going? A review and future potential of modified atmosphere packaging for meat. Meat Sci. 80, 43-65.

29. Pascual, A., Llorca, I., and Canut, A. (2007) Use of ozone in food industries for reducing the environmental impact of cleaning and disinfection activities. Trends Food Sci. Tech. 18, S29-S35.

30. Pradhan, A. A., Rhee, K. S., and Hernández, P. (2000) Stability of catalase and its potential role in lipid oxidation in meat. Meat Sci. 54, 385-390.

31. Renerre, M., Francoise, D., and Gatellier, P. (1996) Antioxidant enzyme activity in beef in relation to oxidation of lipid and myoglobin. Meat Sci. 43, 111-121.

32. Restaino, L., Erampton, E. W., and Hemphill, J. B. (1995) Efficacy of ozonated water against various food-related microorganisms. Appl. Environ. Microb. 61, 3471-3475. 
33. Rhee, K. S., Krahl, L. M., Lucia, L. M., and Acuff, G. R. (2006) Antioxidative/antimicrobial effects and TBARS in aerobically refrigerated beef as related to microbial growth. J. Food Sci. 62, 1205-1210.

34. Sekhon, R. K., Schilling, M. W., Philips, T. W., Aikins, R. M. J., Hasan, M. M., Nannapaneni, R., and Mikel, W. B. (2010) Effects of carbon dioxide and ozone treatments on the volatile composition and sensory quality of dry-cured ham. $J$. Food Sci. 75, 452-458.

35. Sheen, S., Hwang, C., and Juneja, V. K. (2011) Modeling the impact of chlorine on the behavior of Listeria monocytogenes on ready-to-eat meats. Food Microbiol. 28, 1095-1100.

36. Sinnhuber, R. O. and Yu, T. C. (1977) The 2-thiobarbituric acid reaction, an objective measure of the oxidative deterioration occurring in fat and oil. J. Jap. Soc. Fish. Sci. 26, 259267.

37. SPSS (2010) Statistical package for social sciences for Windows (version 19.0). SPSS Inc., Chicago, IL, USA.

38. Stivarius, M. R., Pohlman, F., McElyea, K., and Apple, J. K. (2002) Microbial, instrumental and sensory color and odor characteristics of ground beef produced from beef trimmings treated with ozone and chlorine dioxide. Meat Sci. 60, 299305.
39. Tarladgis, B. G., Watts, B. M., and Younathan, M. T. (1960) Distillation method for the determination of malonaldehyde in rancid foods. J. Am. Oil Chem. Soc. 37, 44-48.

40. Terevinto, A., Ramos, A., Castroman, G., Cabrera, M. C., and Saadoun, A. (2010) Oxidative status, in vitro iron-induced lipid oxidation and superioxide dismutase, catalase and glutathione peroxidase in rhea meat. Meat Sci. 84, 706-710.

41. Unda, J. R., Molins, R. A., and Zamojcin, C. A. (1989) Sanitation of fresh rib eye steaks with chlorine dioxide generating binary systems. J. Food Sci. 54, 7-10.

42. Uradzinski, J., Wysok, B., Bielicki, Z., and Gomólka-Pawlicka, M. (2005) Ozonation as an alternative method of disinfecting knives for use in meat processing. B. Vet. I. Pulawy 49, 399-402.

43. Vitale, M., Perez-Juan, M., Lloret, E., Arnau, J., and Realini, C. E. (2014) Effect of aging time in vacuum on tenderness, and color and lipid stability of beef from mature cows during display in high oxygenatmosphere package. Meat Sci. 96, 270-277.

44. Whiteside, C. and Hassan, H. M. (1988) Role of oxyradicals in the inactivation of catalase by ozone. Free Radical Bio. Med. 5, 305-312.

(Received 2014.6.28/Revised 2014.7.31/Accepted 2014.8.1) 